\title{
Silurian high alumina gabbroic plutons implying an arc setting in East Tianshan, Southern CAOB
}

\author{
BAOYUN CHEN $^{1 *}$, JINJIE YU ${ }^{2}$
}

${ }^{1}$ School of Earth Science and Resources, Chang'an University, Xi'an 710054, China (*Corresponding author: baoyun1114@chd.edu.cn)

${ }^{2}$ MNR Key Laboratory of Metallogeny and Mineral Assessment, Institute of Mineral Resources, CAGS, Beijing 100037, China. (yjjchina@sina.com)

East Tianshan, located in the southern margin of Central Asian Orogenic Belt (CAOB), is absent in real arc gabbroic plutons although several subduction models were previously proposed. Silurian gabbroic assemblages were recently identified in the western East Tianshan, NW China ${ }^{[1]}$. This assemblage includes deformed and serpentinized dunite, olivine clinopyroxenite, wehrlite, troctolite, olivine gabbro and hornblende gabbro. These rocks share three common features: (1) hosting plagioclase with extremely calcic compositions (86 99 mol.\% An) and olivine more iron rich (<85 mol.\%); (2) except hornblende gabbro, other rocks containing spinels extremely rich in alumina and depleted in chromium (Al-spinel, Cr\# <0.001); (3) very rich in hornblendes. Calcic plagioclase and abundant hornblendes reveal high-alumina and water-saturated nature for the parental magmas. The rock assemblages are in line with the deep arc mafic assemblages in Tonsina, Alaska, which firstly defined the zoned Alaska-type mafic-ultramafic complex ${ }^{[2]}$. In addition, the mineral assemblages of calcic plagioclase, Alspinel and iron-rich olivine in the Silurian gabbroic rocks are consistent with those in the Tosina arc plutons, which scarcely occur in other tectonic settings. The cooccurrence of calcic plagioclase and iron-rich olivine further demonstrates an intraoceanic arc setting for the East Tianshan in the Silurian. The CAOB has long been recognized as an important site for the juvenile crustal growth in the world ${ }^{[3]}$. The newly-identified Silurian arc gabbroic assemblages provide evidence for juvenile crustal growth in a form that arc primary magmas would have converted to high alumina basalts or basaltic andesites via deep fractionation of mafic minerals in arc settings. Arc magma fractionation may dominantly contribute to the juvenile crustal growth in the CAOB traverse the Early Paleozoic era.

[1] Chen B.Y. Yu J.J. Liu S.J. (2019), Gondwana Research, 69, 109-126. [2] DeBari \& Coleman (1989), Journal of Geophysical Research: Solid Earth, 94(B4), 4373-4391. [3] Sengör et al. (1993), Nature, 364(6435), 299-307. 